\title{
Effects of a parasite-induced nephritis on osmoregulation in the common carp Cyprinus carpio
}

\author{
Claudia Meyer ${ }^{1}$, Martin Ganter ${ }^{2}$, Wolfgang Körting ${ }^{1}$, Dieter Steinhagen ${ }^{1, *}$ \\ ${ }^{1}$ Fish Disease Research Unit, and ${ }^{2}$ Clinic for Pigs and Small Ruminants, School for Veterinary Medicine Hannover, \\ PO Box 7111 80, 30545 Hannover, Germany
}

\begin{abstract}
Carp Cyprinus carpio infected with the haemoflagellate Trypanoplasma borreli undergo progressive nephritis associated with a destruction of approx. $40 \%$ of the nephric tubules. In an attempt to analyse the effect of the nephritis on the osmoregulation of affected carp, the clinical chemical properties of plasma and urine samples were analysed. Parasitised carp excreted greater amounts of electrolytes in their urine than uninfected carp which excreted highly diluted urine with an osmolality of about $10 \%$ of plasma osmolality. During the course of the infection, urine osmolality increased up to $26 \%$ of plasma osmolality by Day 21 post-infection (p.i.). The plasma:urine ratio of $\mathrm{Na}^{+}$also increased, while concomitant losses of $\mathrm{Mg}^{2+}, \mathrm{Ca}^{2+}, \mathrm{K}^{+}$and inorganic phosphate were less pronounced. Infected carp were able to maintain a normal solute balance in their plasma. Plasma hydration (indicated by decreased protein contents) occurred on Day 21 p.i. Our data indicate that in T. borreli-infected carp, reabsorption processes of the distal renal tubule were disturbed, while secretory and absorption processes in the proximal tubule appeared to be less affected. In addition, infected carp were able to compensate their increased ion losses, probably by (energy-consuming) active absorption processes. The energy budget of infected carp was additionally affected by a substantial direct consumption of plasma glucose by the parasite.
\end{abstract}

KEY WORDS: Cyprinus carpio - Nephritis · Osmoregulation · Plasma/urine biochemistry . Trypanoplasma borreli

Resale or republication not permitted without written consent of the publisher

\section{INTRODUCTION}

The kidney of teleosts is a complex organ, comprising haematopoietic, lymphatic, endocrine and excretory tissues. In freshwater fishes, the excretory tissue produces large quantities of very dilute urine to counteract the constant influx of water that passes across their gills during respiration (Elger et al. 2000). Renal sinusoids and capillaries, however, are lined by high numbers of phagocytes, which play a major role in trapping antigens from the circulatory fluid (Ferguson 1989). As a result, particulate antigens such as bacteria are often deposited as macrophage aggregates in the interstitium (Wolke 1992). These macrophage aggregates may become the focus of granulomata formation,

${ }^{*}$ Corresponding author.

E-mail: dieter.steinhagen@tiho-hannover.de especially in diseases such as nocardiosis, mycobacteriosis or amoebiasis, in which the antigen persists (Ferguson 1989, Lom \& Dyková 1992). In addition, the lymphoid tissue in the interstitium responds to antigen challenge by inflammatory and proliferative changes, which may be accompanied by degenerative changes in excretory elements. For instance, haematopoietic hyperplasia coinciding with the loss of tubules was seen in proliferative kidney disease in salmonids (Clifton-Hadley et al. 1987) and in carp infected with the blood parasite Trypanoplasma borreli (Lom \& Dyková 1992, Bunnajirakul et al. 2000). In T. borreliinfected carp, cytological alterations of renal tubule epithelium cells comprising the loss of basilar invaginations and destruction of mitochondria were initially seen in the distal tubule segment and, with increasing development of the parasite, in the proximal tubule as well (Rudat et al. 2000). 
The kidney of teleosts has no role in the excretion of toxic ammoniacal compounds, but plays an important role in ionic and osmotic regulation (Hentschel \& Elger 1987, Evans 1993). Alterations in renal epithelium cells can result in functional disorders affecting the osmoregulation of affected fishes.

In mammals suffering from progressing loss of nephrons due to inflammatory-proliferative nephropathies, the filtration rate of intact nephrons increases due to auto-regulative processes. Tubular processes such as secretion of potassium and re-absorption of sodium and water do not intensify correspondingly. As a result, polyuria with decreasing urine osmolality is observed in cases in which $50 \%$ or less of the nephrons remain intact (David et al. 1995). With further losses of filtrating nephrons, the glomerular filtration rate decreases, finally resulting in uraemia.

Very few nephro-pathological studies have been made on fishes. Rainbow trout Oncorhynchus mykiss suffering acute viral haemorrhagic septicaemia, which is comparable with kidney necrosis, exhibited an oligouria with a concomitant decrease in glomerular filtration rate (GFR) from 5.20 to $3.08 \mathrm{ml} \mathrm{h}^{-1} \mathrm{~kg}^{-1}$ and a reduction in urine flow from 2.50 to $1.63 \mathrm{ml} \mathrm{h}^{-1} \mathrm{~kg}^{-1}$. The urine of infected rainbow trout was of higher osmolality compared to uninfected trout, but the plasma osmolality remained unchanged (Elger et al. 1986). Common carp suffering from hypoxia reduced their urine flow from 3.4 to $0.1 \mathrm{ml} \mathrm{h}^{-1} \mathrm{~kg}^{-1}$, and displayed an increased level of electrolytes (Kakuta et al. 1992).

In the present study, we examined the nephric function in carp infected with the blood-dwelling flagellate Trypanoplasma borreli. Carp from a strain that is highly susceptible to the parasite were injected with $T$. borreli, and during development of the parasitaemia, urine and blood samples were collected and analysed. In an attempt to correlate biochemical data to histopathological findings, histological samples of the kidney were examined as well. In order to estimate other sources of energy utilisation in T. borreli-infected carp, we also attempted to determine the glucose consumption of the parasite itself.

\section{MATERIALS AND METHODS}

Fish. Parasite-free carp Cyprinus carpio from a single crossing $(\mathrm{E} 20 \times \mathrm{R} 8$ : Wageningen Agricultural University, The Netherlands) were used throughout this study. Carp were propagated and raised under parasite-free conditions in closed laboratory facilities in fibreglass tanks filled with filtered recirculating tap water at $20 \pm 2{ }^{\circ} \mathrm{C}$. The fish-raising conditions precluded previous infections with the parasite, and tissues of fishes from the same stock were checked for the presence of parasites on a regular basis. Fish larvae were fed initially with Artemia sp. Nauplii (hatched from Sanders Great Salt Lake Artemia cysts), and the feeding regime was then switched to commercial carp chow (Trouvit, Trow, The Netherlands). Carp used in the experiments were sexually immature and had a body weight of approx. $100 \mathrm{~g}$.

Parasite infection. For infection experiments, Trypanoplasma borreli from a cloned strain were used (Steinhagen et al. 1989). The parasites were maintained in the laboratory by syringe passage through parasite-free carp. For the experiments in the current study, 21 carp were infected by injecting $50 \mu \mathrm{l}$ phosphate-buffered salt solution (PBS) containing 5000 viable $T$. borreli into their dorsal muscle; they were kept at $20 \pm 2{ }^{\circ} \mathrm{C}$. For controls, 9 carp were injected with $50 \mu \mathrm{l}$ PBS alone.

Urine and blood sampling. Carp urine was sampled with a urinary catheter, and blood for plasma determinations was drawn from the caudal blood vessels.

For urine samples, parasite-infected and control carp were anaesthetised by immersion in a solution of $0.15 \mathrm{~g} \mathrm{l}^{-1}$ aminobenzoic acid ethyl ester (Tricaine, Sigma) at 7, 14, and $21 \mathrm{~d}$ p.i. and then placed, ventral side up, in a V-shaped block on a surgical table (Klontz \& Smith 1968) providing a constant flow of aerated water with $0.7 \mathrm{~g} \mathrm{l}^{-1}$ tricaine over the skin and gills. The urinary catheter was custom-made from polyethylene tubing with an internal diameter of $0.86 \mathrm{~mm}$ and a length of $\sim 40 \mathrm{~cm}$. One end of the tubing was widened to a funnel by heating over an ethanol flame, and was perforated with a hot needle (Elger et al. 2000). The catheter was completely filled with sterile distilled water by means of a syringe, inserted into the urinary bladder and fixed as described by Kakuta et al. (1986). Anchoring sutures were made around the uroporus, and the widened end of the catheter was inserted into the uroporus to a depth of 3 to $4 \mathrm{~cm}$. The sutures were then tightened to fix the catheter in the uroporus, and additional anchoring sutures were made on the urogenital papilla and in the lateral body musculature about $2 \mathrm{~cm}$ above the uroporus. The catheter was tested for urine flow by removing the syringe. The fish were then placed individually into a restraining system holding $12 \mathrm{l}$ of recirculated filtered tap water. The loose end of the catheter was connected to a chilled $50 \mathrm{ml}$ disposable tube, which was placed next to the holding tank. The urine was collected continuously into these tubes. To avoid any influence of laboratory diuresis caused by anaesthesia and catheter insertion, the urine collected during the first $24 \mathrm{~h}$ after catheterization was discarded. For analysis, urine was collected for an additional $6 \mathrm{~h}$ at least, and kept frozen at $-20^{\circ} \mathrm{C}$ until use. Sufficient urine for the analysis was obtained from 20 carp only. 
For blood samples, the carp were again anaesthetised with tricaine $48 \mathrm{~h}$ after catheterisation, and blood was drawn from the caudal vessels into disposable syringes with beads containing lithium-heparin (Sarstedt). From the blood, haematological data such as haematokrit and haemoglobin contents and abundance of red blood cell and parasites were recorded. In addition, a portion of the blood samples was centrifuged at $600 \times g$ for $15 \mathrm{~min}$ (Biofuge A), the supernatant plasma was collected and frozen at $-20^{\circ} \mathrm{C}$ until use.

Histology. The carp were necropsied and a small piece of tissue was immediately collected from the right portion of the trunk kidney and fixed with phosphate-buffered formalin (4\% w/v, $\mathrm{pH} 7.2)$. The tissue was dehydrated in a series of graded ethanols, infiltrated and embedded with glycol methacrylate (Technovit 7100). Sections were stained with Giemsa (Romeis 1989) and observed with a Zeiss photomicroscope. From each tissue sample, at least 400 renal tubules were examined for tissue damage.

Haematological and chemical analyses. Determination of the haematokrit and haemoglobin content and red blood cell abundance as well as the derived indices of mean erythrocyte volume (MEV) and mean erythrocytic haemoglobin (MEH) were determined using standard methods (Houston 1990). The osmolality of the urine and plasma samples was measured using a cryo-osmometer (Vogel). Potassium and sodium levels were determined with a flame photometer (Bayer Diagnostics). Magnesium and calcium concentrations were measured colorimetrically, calcium concentrations were determined by means of complex formation with cresolphthalein complexone (Roche), and magnesium with calmagite (Sigma). Phosphate was determined colorimetrically as a phosphomolybdate complex (Merck), and ammonia according to Berthelot's reaction by means of indophenol formation (Spektroquant Ammonia; Merck). The bilirubin content of the plasma was determined colorimetrically according to the 'Jendrassik-Grof-method' in the presence of caffeine-benzoate-acetate. The plasma glucose concentration of some samples was determined by means of the 'glucoquant' assay (Roche Catalogue No. 1442457) according to the manufacturer's instructions.

The activity of alkaline phosphatase in the urine and plasma samples was measured colorimetrically by formation of $p$-nitrophenyl from $p$-nitrophenyl phosphate, which is catalysed by the enzyme alkaline phosphatase (Roche). The enzyme $\gamma$-glutamyl-transferase catalyses the reaction of L- $\gamma$-glutamyl-3-carboxy-4-nitroaniline and glycylglycine to $\gamma$-glutamyl-glycylglycid and 3-carboxy-4-nitroanilin. The product 3-carboxy4-nitroanilin is yellow in colour and its intensity is measured photometrically (Roche). The plasma protein concentration was measured by a refractometer (Obladen).

Glucose consumption of Trypanoplasma borreli. To estimate glucose consumption of the trypanoplasmas, 10 carp were injected with $5000 \mathrm{~T}$. borreli and 10 carp with PBS as described above. On Day 21 p.i., peripheral blood was drawn from infected and control carp. For each carp, flagellate abundance in the blood was determined and 1 portion of the blood sample was immediately centrifuged at $600 \times g$, the plasma was then collected and frozen at $-20^{\circ} \mathrm{C}$. A second portion of the blood sample was incubated at $20^{\circ} \mathrm{C}$ for $2 \mathrm{~h}$, centrifuged, and the plasma collected and frozen at $-20^{\circ} \mathrm{C}$. For both plasma portions, glucose concentrations were measured and an index was calculated from the postincubation/pre-incubation glucose levels.

Statistical methods. Data were analysed by 1-way ANOVA when distributed normally. If the test for normal distribution failed, the data were analysed by ANOVA on ranks. Differences were considered to be significant at $\mathrm{p}<0.05$.

\section{RESULTS}

\section{Development of parasitaemia}

A parasitaemia with Trypanoplasma borreli was detected in the peripheral blood of all carp sampled 14 and $21 \mathrm{~d}$ p.i. (Table 1). Corresponding to the development of the parasitaemia, infected carp developed anaemia, with a decreasing abundance of erythrocytes, and decreasing haematokrit and haemoglobin values (Table 1). The mean erythrocyte volume varied within a wide range, but did not change significantly during the development of the parasitaemia, while the mean haemoglobin content of the red blood cells increased significantly from 43.1-68.5 pg (mean $60.8 \mathrm{pg}$ ) in uninfected carp to $76.3-138.0 \mathrm{pg}$ (mean 92.1 pg) on Day 21 p.i.

In the kidney, progressive proliferation of interstitial lymphoid tissue together with a degeneration of renal tubules accompanied the development of the parasitaemia (Figs. 1 \& 2, Table 2). As monitored on histological sections, $13.8 \pm 5.3 \%$ of the tubules were damaged by Day 14 p.i., and $37.6 \pm 5.7 \%$ by Day 21 p.i. (Table 2). In addition to anaemia, the carp sampled on Day 21 p.i. showed abdominal distension and exophthalmus.

\section{Clinical chemistry of carp urine and plasma}

To determine if the parasite-induced atrophy of the kidney tubules interfered with osmoregulation and 
Table 1. Cyprinus carpio. Haematology and parasitaemia of carp with laboratory-induced Trypanoplasma borreli-infection. d p.i.: days post-infection, MEV: mean erythrocyte volume, MHC: mean haemoglobin contents of erythrocyte. Controls were PBSinjected. Numbers of carp examined in brackets

\begin{tabular}{|lcccccc|}
\hline d p.i. & $\begin{array}{c}\text { Haematokrit } \\
\left(\mathrm{l} \mathrm{l}^{-1}\right)\end{array}$ & $\begin{array}{c}\text { Erythrocytes } \\
\left(\times 10^{12} \mathrm{l}^{-1}\right)\end{array}$ & $\begin{array}{c}\text { Haemoglobin } \\
\left(\mathrm{g} \mathrm{l}^{-1}\right)\end{array}$ & $\begin{array}{c}\text { MEV } \\
\left(\mu \mathrm{m}^{3}\right)\end{array}$ & $\begin{array}{c}\text { MHC } \\
(\mathrm{pg})\end{array}$ & $\begin{array}{c}\text { T. borreli } \\
\left(\times 10^{12} \mathrm{l}^{-1}\right)\end{array}$ \\
\hline Controls (9) & $0.38 \pm 0.03$ & $1.67 \pm 0.40$ & $104.8 \pm 25.8$ & $237.1 \pm 47.6$ & $64.6 \pm 18.5$ & - \\
$7(8)$ & $0.34 \pm 0.10$ & $1.44 \pm 0.30$ & $96.0 \pm 30.7$ & $233.6 \pm 51.3$ & $66.2 \pm 15.8$ & $0.001 \pm 0.01$ \\
$14(7)$ & $0.30 \pm 0.05$ & $1.40 \pm 0.19$ & $87.9 \pm 13.6$ & $214.6 \pm 29.3$ & $63.1 \pm 6.6$ & $0.014 \pm 0.02$ \\
$21(5)$ & $0.15 \pm 0.08$ & $0.73 \pm 0.31$ & $66.0 \pm 18.2$ & $196.1 \pm 28.7$ & $97.3 \pm 24.4$ & $0.154 \pm 0.11$ \\
\hline
\end{tabular}

Table 2. Cyprinus carpio. Proportion of damaged tubuli in the kidney of carp infected with Trypanoplasma borreli. d p.i.: days post-infection with the parasites. Proportion of damaged tubuli was determined from histological sections, at least 400 renal tubule sections were evaluated for each carp. Controls were PBS-injected

\begin{tabular}{|lcc|}
\hline d p.i. & $\begin{array}{c}\text { Percent of } \\
\text { damaged tubuli }\end{array}$ & $\begin{array}{c}\text { No. of } \\
\text { carp examined }\end{array}$ \\
\hline Controls & $2.8 \pm 1.0$ & 9 \\
7 & $8.8 \pm 7.8$ & 8 \\
14 & $13.8 \pm 5.3$ & 7 \\
21 & $37.6 \pm 5.7$ & 5 \\
\hline
\end{tabular}

urine excretion of infected carp, urine and plasma were collected from infected and uninfected carp and analysed for ion content. Plasma osmolality as well as the concentration of $\mathrm{Mg}^{2+}, \mathrm{Na}^{+}$and phosphate in Trypanoplasma borreli-infected carp was within the range measured for uninfected controls (Fig. 3). The $\mathrm{Ca}^{2+}$ concentration increased only slightly $(p=0.06)$ from 1.0-2.6 (mean 1.5) $\mathrm{mM}$ in uninfected carp to 1.5-2.8 (mean 2.5) mM by Day 21 p.i. The plasma protein level and the bilirubin concentration remained within the range of uninfected carp up to $14 \mathrm{~d}$ p.i., at which time the damage to the renal tubules did not exceed $20 \%$ (see Table 2). On Day 21 p.i., when approx. $40 \%$ of the tubules were affected, the protein level dropped and the bilirubin concentration increased significantly (Fig. 1). With increasing tissue damage to the renal tubules, plasma potassium levels and the activity of alkaline phosphatase in the plasma increased (Fig. 3).

The atrophy of the kidney tubules in Trypanoplasma borreli-infected carp (Fig. 2) did not affect their urine secretion significantly. Uninfected carp excreted 2.6-10.2 ml urine $\mathrm{kg}^{-1} \mathrm{~h}^{-1}$ (mean $7.4 \mathrm{ml}$ $\mathrm{kg}^{-1} \mathrm{~h}^{-1}$ ). On Days 7 and 14 , the urine flow decreased slightly to approx. $6.0 \mathrm{ml} \mathrm{kg}^{-1} \mathrm{~h}^{-1}$, but this had recovered to values of about $7.0 \mathrm{ml} \mathrm{kg}^{-1} \mathrm{~h}^{-1}$ by Day 21 p.i. Fig. 4 shows that in T. borreli-infected carp urine production was within the range measured for uninfected controls. Healthy carp excreted highly diluted urine with an osmolality of 20-40 (mean 27.5) mOsmol $\mathrm{l}^{-1}$, about $10 \%$ of plasma osmolality (Figs. 3 \& 4, Table 3). With T. borreli infection, urine osmolality increased to 40-77 (mean 45.0, SE 14.9) $\mathrm{mOsm} \mathrm{l}^{-1}$ by Day 14 p.i., and $70.5 \mathrm{mOsm} \mathrm{l}^{-1}$ by Day 21 p.i., i.e. an increase in the plasma:urine ratio from $0.1-0.22$ and 0.26 , respectively. The increase in urine osmolality was mainly due to increased excretion of sodium, which rose from 4.0-10.0 (mean 7.3) $\mathrm{mM}$ in the urine of uninfected carp to 10-55 (mean
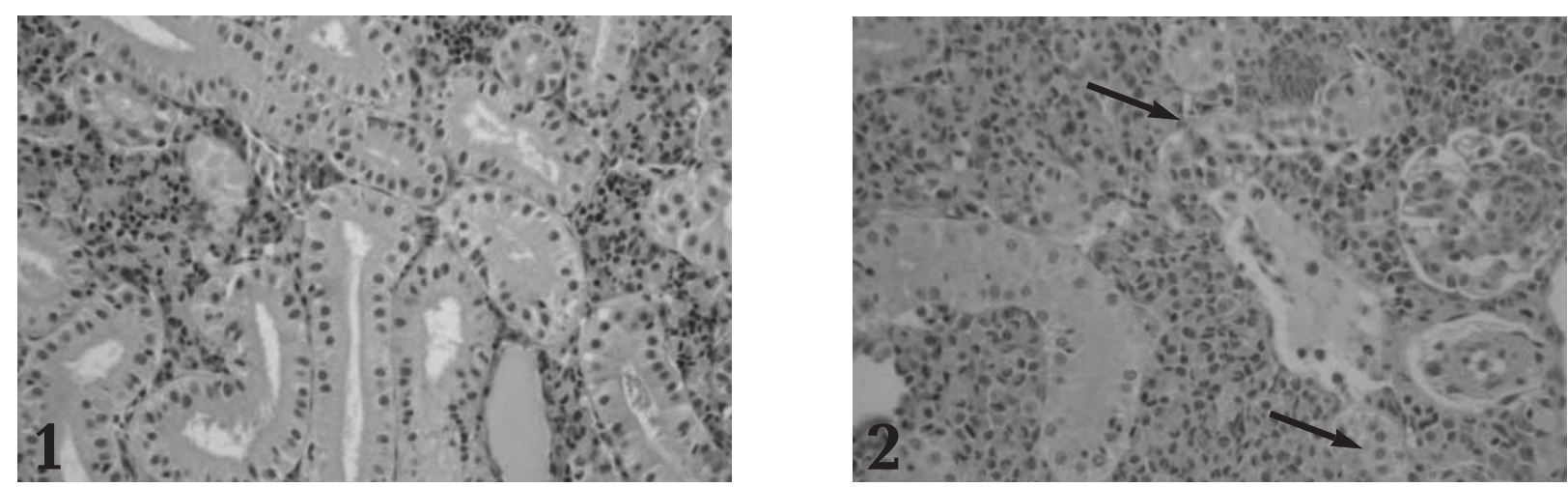

Figs. 1 \& 2. Cyprinus carpio. Fig. 1. Histology of trunk kidney, showing numerous cross-sections of renal tubules and a narrow interstitial tissue (×95). Fig 2. Carp infected by Trypanoplasma borreli on Day 21 post infection (p.i.), in the kidney, a massive proliferation of the interstitial tissue has occurred, and renal tubules are atrophied (arrows) $(\times 95)$ 

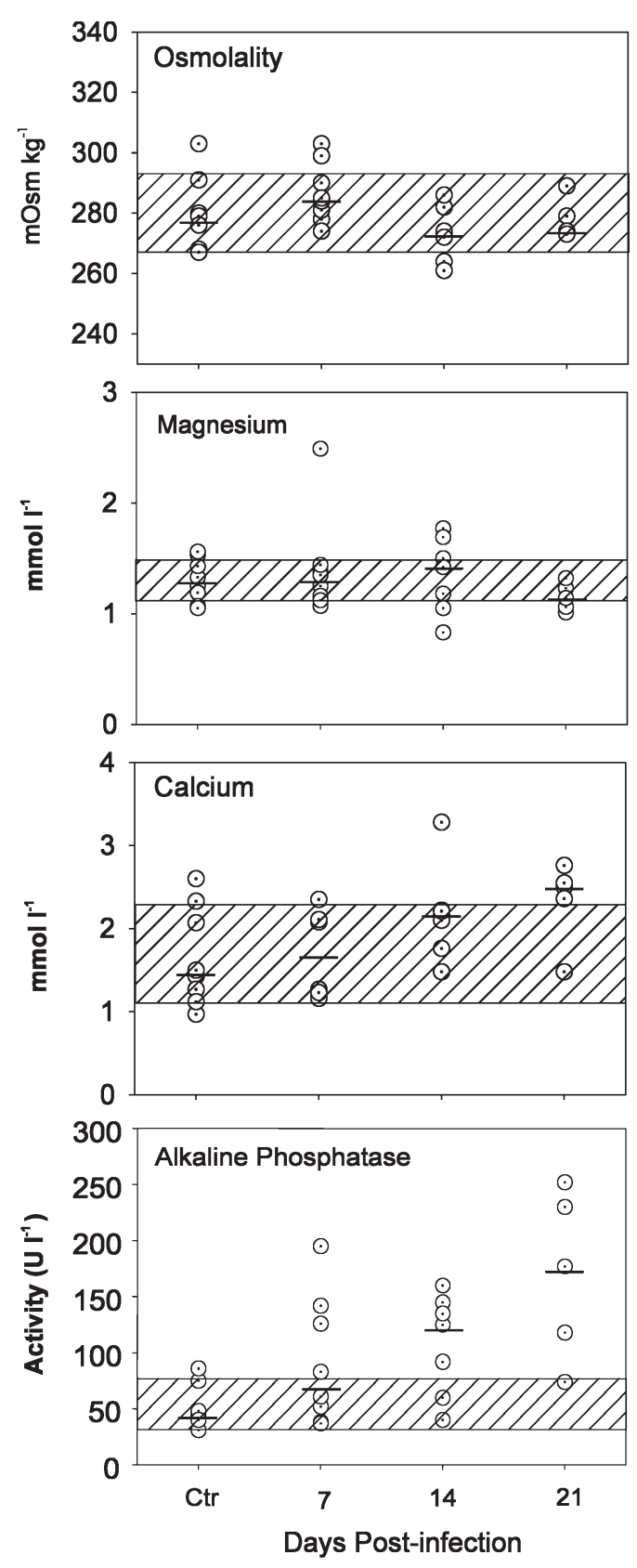
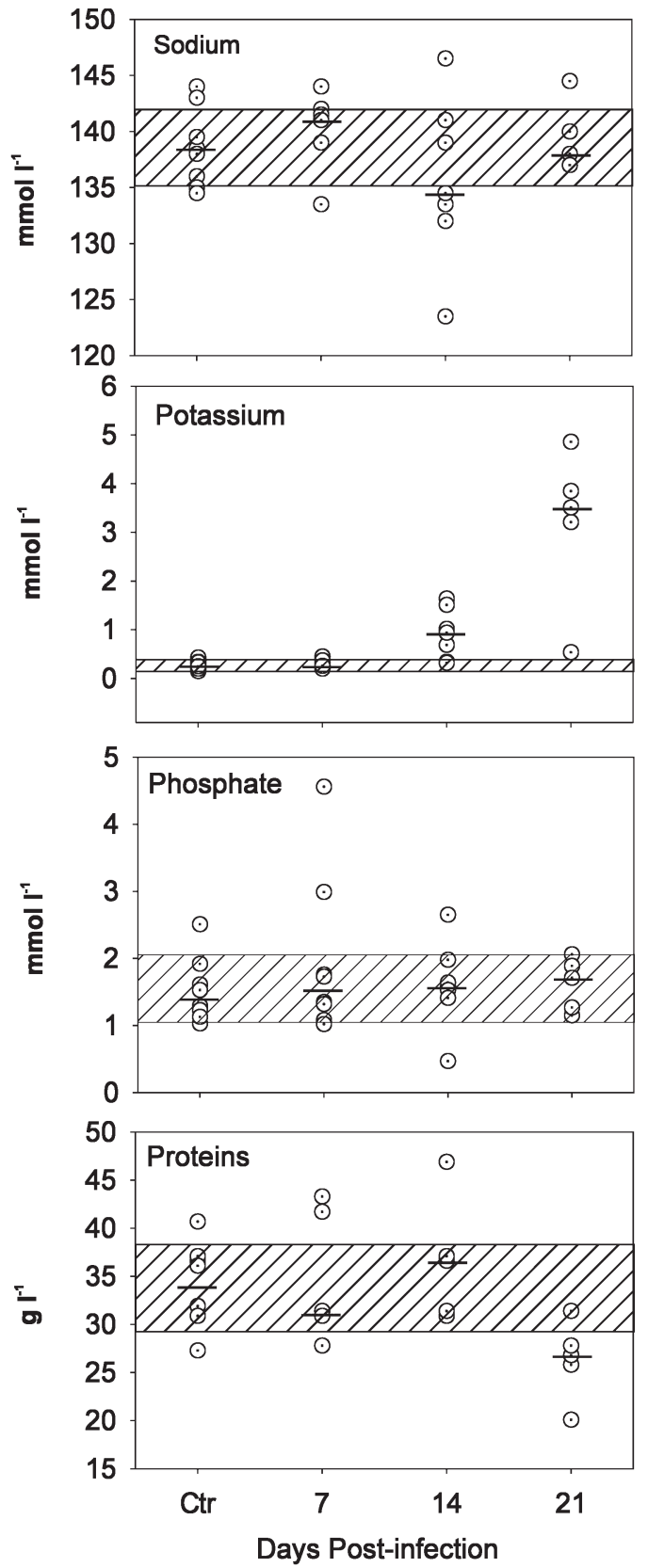

Fig. 3. Cyprinus carpio. Effect of Trypanoplasma borreli-induced nephritis on some chemical properties of carp plasma, showing measurements for individuals and mean values (-) for 8 (Day 7 p.i.), 7 (Day 14 p.i.), and 5 (Day 21 p.i.) infected carp, and 9 PBSinjected control (Ctr) carp. Hatched boxes indicate SDs for control carp

27.0) $\mathrm{mM}$ in infected carp by Day 21 p.i. The plasma:urine ratio of $\mathrm{Na}^{+}$increased from 0.06 in uninfected carp to 0.18 and 0.20 in infected carp by Days 14 and 21 p.i. (Table 3). The loss of ions such as $\mathrm{Mg}^{2+}, \mathrm{Ca}^{2+}, \mathrm{K}^{+}$and phosphate increased also, but to a lower extent (Fig. 4). As a result, the plasma:urine ratio of $\mathrm{Mg}^{2+}$ and inorganic phosphate increased slightly, while that for $\mathrm{Ca}^{2+}$ remained stable (Table 3).
The urine of infected and uninfected carp alike contained no sediment or haemoglobin, and had a very low alkaline phosphatase activity (range 2.0-10.9 $\mathrm{U} \mathrm{l}^{-1}$ ), which did not change during the parasitaemia. The activity of $\gamma$-glutamyl-transferase ranged between 0.1 and $4.3 \mathrm{U} \mathrm{l}^{-1}$ (mean $2.6 \mathrm{U} \mathrm{l}^{-1}$ ) in uninfected carp. This had increased slightly to $1.4-5.2$ (mean $4.6 \mathrm{U} \mathrm{l}^{-1}$ ) by Day 21 p.i., when severe pathology was observed in the kidney sections. 

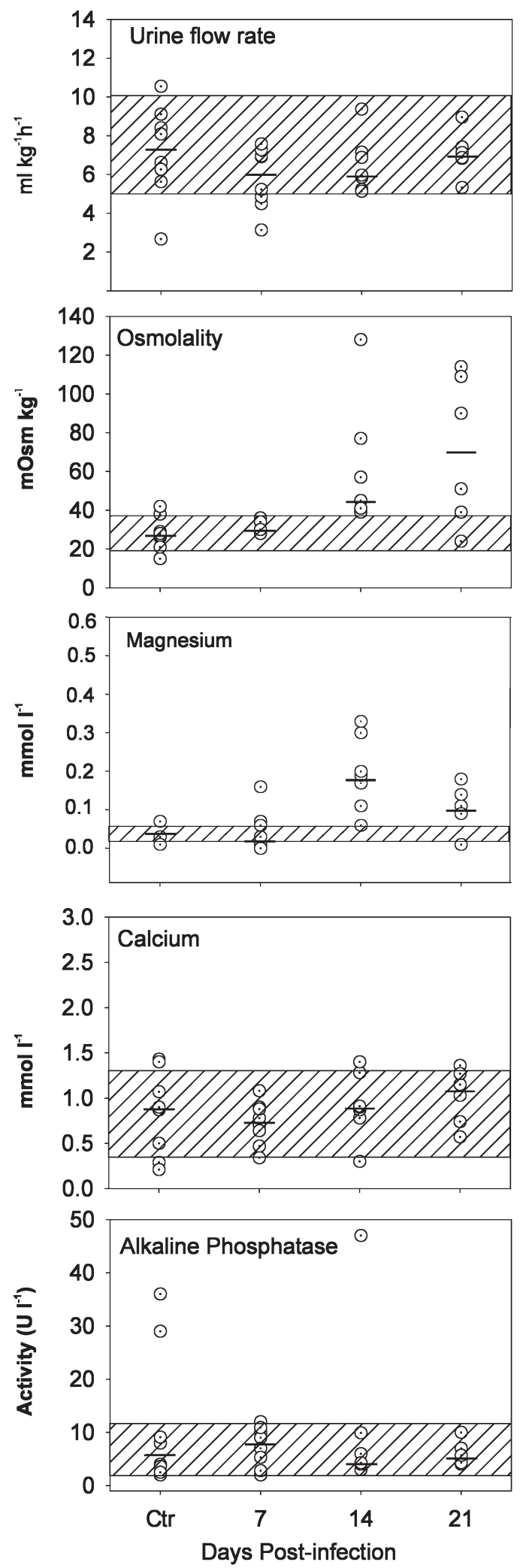
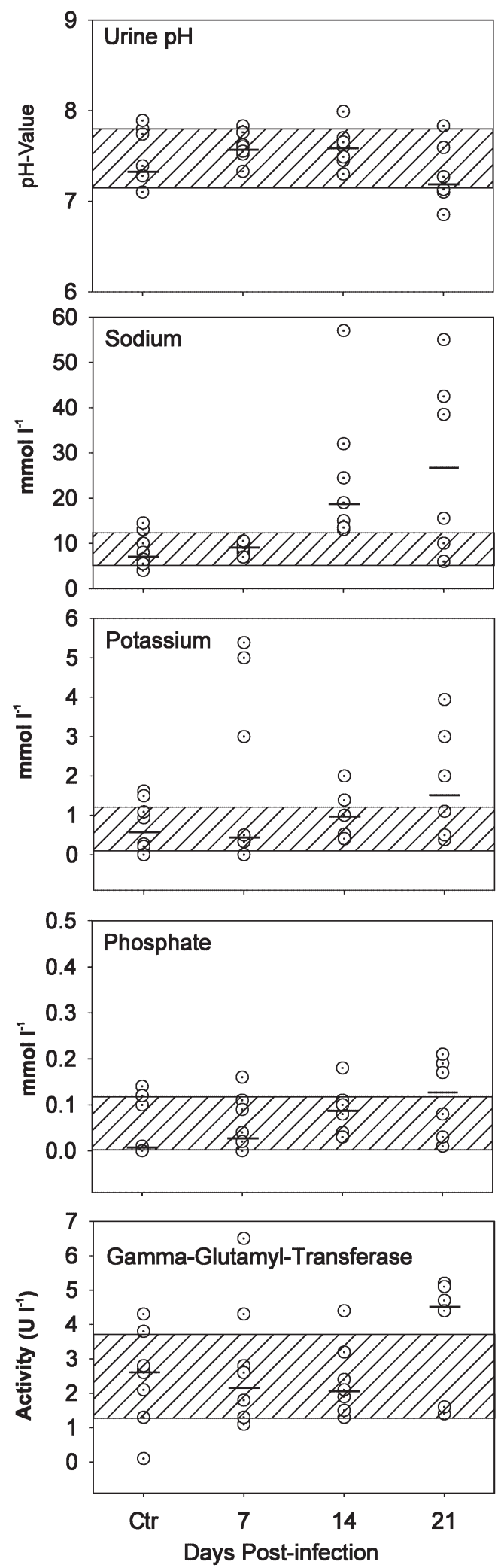

Fig. 4. Cyprinus carpio. Effect of Trypanoplasma borreli-induced nephritis on chemical properties of carp urine, showing measurements for individuals and mean values (-) for 8 (Day 7 p.i.), 7 (Day 14 p.i.), and 5 (Day 21 p.i.) infected carp and 9 PBS-injected control (Ctr) carp. Hatched boxes indicate SDs for control carp 
Table 3. Cyprinus carpio. Plasma:urine ratios of electrolytes in carp with laboratory-induced Trypanoplasma borreli-infection. d p.i.: days post-infection, Pi: inorganic phosphate

\begin{tabular}{|lcccccc|}
\hline d p.i. & Osmolality & $\mathrm{Mg}^{2+}$ & $\mathrm{Ca}^{2+}$ & $\mathrm{Na}^{+}$ & $\mathrm{K}^{+}$ & $\mathrm{Pi}$ \\
\hline Controls & 0.10 & 0.03 & 0.50 & 0.06 & 2.50 & 0.03 \\
7 & 0.11 & 0.03 & 0.42 & 0.07 & 6.36 & 0.02 \\
14 & 0.22 & 0.14 & 0.42 & 0.18 & 1.04 & 0.12 \\
21 & 0.26 & 0.09 & 0.44 & 0.20 & 0.57 & 0.07 \\
\hline
\end{tabular}

Uninfected carp excreted 4.2 to $12.0 \mathrm{mg} \mathrm{l}^{-1}$ ammonia with their urine. Infected carp, at Day 7 p.i., excreted $4.0 \mathrm{mg} \mathrm{l}^{-1}$ (range 2.3-10.3 $\mathrm{mg} \mathrm{l}^{-1}$ ). On Days 14 and 21, infected carp excreted ammonia within the same range (4.2-12.0 $\mathrm{mg} \mathrm{l}^{-1}$ ) as determined for uninfected carp (data not shown).

\section{Glucose utilisation by Trypanoplasma borreli}

Blood samples from infected and uninfected carp were incubated at $20^{\circ} \mathrm{C}$ for $2.5 \mathrm{~h}$. Comparison of postincubation glucose concentrations of plasma to preincubation concentrations of samples from the same individuals revealed a decrease that could be related to the number of trypanoplasms present in the sample. Glucose concentrations in uninfected carp were 96$99 \%$ of the pre-incubation levels. In infected carp, the glucose concentrations decreased to $25-88 \%$ of the

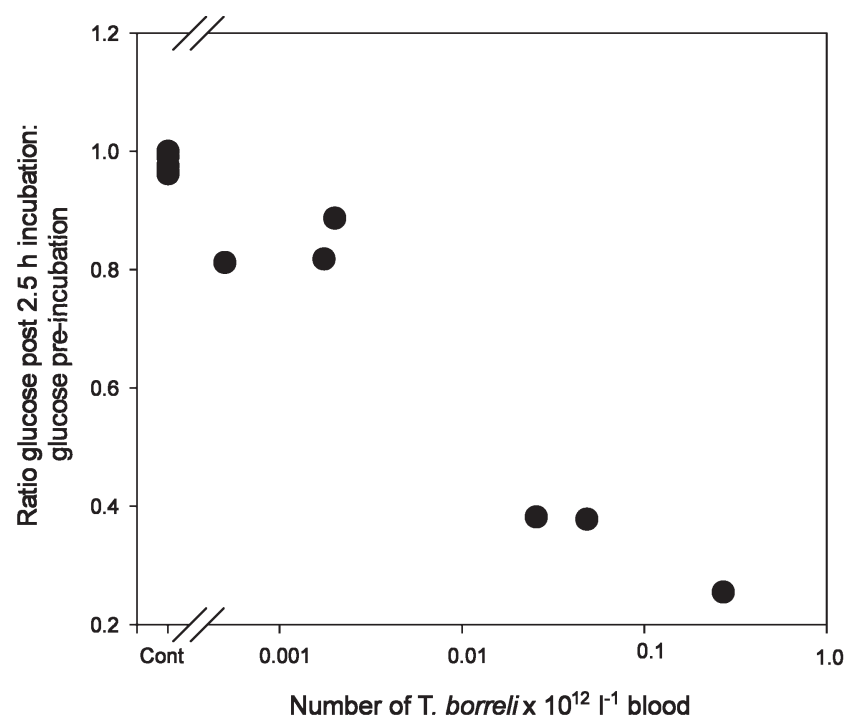

Fig. 5. Trypanoplasma borreli. Plasma glucose consumption by $T$. borreli, showing ratio of glucose concentration post $(2.5 \mathrm{~h})$-incubation at $20^{\circ} \mathrm{C}$ : glucose concentration pre-incubation in relation to the number of $T$. borreli present in the blood samples. Cont: uninfected control carp pre-incubation levels, depending on the number of trypanoplasms present in the samples (Fig. 5). Our results suggest a substantial consumption of plasma glucose by trypanoplasms.

\section{DISCUSSION}

Teleost fishes are hyper-osmotic to the freshwater environment and experience a substantial influx of water (about $50 \%$ of body water $\mathrm{h}^{-1}$; Evans 1993). Offsetting this osmotic uptake of water, freshwater teleosts produce high quantities of urine by maintaining a relatively high glomerular filtration rate of 4.3 to $5.3 \mathrm{ml} \mathrm{kg} \mathrm{h}^{-1}$ in rainbow trout Oncorhynchus mykiss, or $6.0 \mathrm{ml} \mathrm{kg}^{-1} \mathrm{~h}^{-1}$ in carp, and an only slightly reduced urine flow of $2.5-3.5 \mathrm{ml} \mathrm{kg}^{-1} \mathrm{~h}^{-1}$ in rainbow trout (Elger et al. 1986, Wood \& Patrick 1994) or 3.4-5.0 ml kg-1 $\mathrm{h}^{-1}$ in carp (Kakuta et al. 1992, Wood \& Patrick 1994). Of the glomerular filtrate electrolytes, mainly $\mathrm{NaCl}$ is conserved by re-absorption in the distal segment of the nephric tubule, resulting in a urine osmolality of approx. $30 \mathrm{mOsm}^{-1}$ in carp (Kakuta et al. 1992 and present study), which is about $10 \%$ of plasma osmolality. Under pathological conditions such as hypoxia in carp or an acute infection of rainbow trout with viral haemorrhagic septicaemia, reduced urine flow rates to $0.1 \mathrm{ml} \mathrm{kg}^{-1} \mathrm{~h}^{-1}$ in carp (Kakuta et al. 1992) and $1.6 \mathrm{ml} \mathrm{kg}^{-1} \mathrm{~h}^{-1}$ in rainbow trout (Elger et al. 1986) have been reported. In the interstitial nephritis induced by an infection with the blood flagellate Trypanoplasma borreli, studied herein, urine flow was not altered significantly despite a progressive atrophy of the kidney tubules of approx. $40 \%$ by Day 21 p.i. This could be the result of increased urine flow rates in intact tubules due to elevated glomerular filtration. In addition, studies on isolated nephrons of the dogfish shark Squalus acanthias indicated that active secondary transport of chlorine in the proximal tubule was a mechanism of fluid secretion in fishes (Beyenbach 1995).

In Trypanoplasma borreli-infected carp, urine osmolality increased by up to $25 \%$ of plasma osmolarity, indicating an increased loss of electrolytes through the urine. The carp experienced a substantial loss of $\mathrm{Na}^{+}$, which was already elevated on Day 7 p.i. and had increased by a factor of 6 by Day 21 p.i. (at the end of the observation period). The re-absorption of $\mathrm{Na}^{+}$from the urine, driven by Na-K-ATPase, occurs in the epithelium of the distal tubule segment (Elger et al. 2000). In carp infected by $T$. borreli, these cells responded by fragmentation of basilar invaginations and swelling of mitochondria as early as Day 7 p.i., and with increasing development of the parasitaemia the damage to the cellular structures progressed rapidly 
(Rudat et al. 2000). The cytological changes appear to impair the re-absorption of sodium chloride to such an extent that elevated sodium levels in the urine were manifest as early as Day 14 p.i., when 85 to $90 \%$ of the tubules still appeared to be intact when examined histologically.

In the kidney of rainbow trout with viral haemorrhagic septicaemia, the net re-absorption for $\mathrm{Na}^{+}, \mathrm{K}^{+}$ and $\mathrm{Ca}^{2+}$ was reduced, and the concentration of $\mathrm{Mg}^{2+}$, $\mathrm{Ca}^{2+}$ and $\mathrm{Na}^{+}$in the urine increased (Elger et al. 1986). In our experiments, the phosphate and magnesium concentrations in the urine had increased from 3-12 and $14 \%$, respectively, of the plasma concentrations by Day 14 p.i., and had decreased to 9 and $7 \%$, respectively, by Day 21 p.i. The urine:plasma ratios of calcium remained stable. In fishes, the secretion of bivalent ions such as $\mathrm{Mg}^{2+}$ as well as the secretion and reabsorption of inorganic phosphate are considered to take place in the proximal tubule (Beyenbach 1995, Elger et al. 2000). In our study, the cells of the proximal segment appeared to be much less affected by the parasite infection than those of the distal tubule. Cytological changes such as fragmentation of basilar infoldings, mitochondria and cell-swelling were first seen on Day 14 and had become more prominent by Day 21 p.i. (Rudat et al. 2000). Our experiments indicate an increased $\mathrm{Mg}$ and P leakage up to Day 14, with partial recovery by Day 21 p.i. This could indicate a reduced glomerular filtration rate up to Day 21 p.i., but the mechanisms underlying these phenomena need to be studied.

The proximal tubule is the principal site of reabsorption of substances such as low molecular-weight proteins, amino acids or sugars (reviews by Beyenbach 1995, Elger et al. 2000). In Trypanoplasma borreliinfected carp, a proteinuria (which might indicate disturbance of these processes) was not seen, and plasma protein levels remain stable in infected carp up to Day 14 p.i. In addition, alkaline phosphatase, which is located in the cells of the proximal tubule of the teleost kidney (Scheinert \& Hoffmann 1987, Elger et al. 2000) did not increase in the urine of parasitised carp. In veterinary medicine, cellular leakage of kidney tubules is monitored by the analysis of $\gamma$-glutamyl-transferase (GGT) as an early predictor of acute tubular necrosis (Cowgill \& Elliott 2000). In our study, increased activity of GGT in the urine of infected carp was not determined before Day 21 p.i., when histology revealed a proportion of deteriorating kidney tubules of about $40 \%$. To evaluate the diagnostic value of these enzymes in the recognition of nephropathies, additional data are needed.

To compensate for the constant efflux of electrolytes in their urine, freshwater fishes accumulate salts, primarily $\mathrm{Na}^{+}$and $\mathrm{Cl}^{-}$by active absorption from pond water, which occurs within the apical membrane of branchial cells. The current model of $\mathrm{NaCl}$ uptake involves 2 antiporters, $\mathrm{Na} / \mathrm{H}$ exchange and $\mathrm{Cl} / \mathrm{HCO}_{3}{ }^{-}$ exchange, working in parallel (Wright 1991). Despite elevated losses with their urine, Trypanoplasma borreli-infected carp were able to maintain their plasma osmolality, Mg, Na and phosphate levels within narrow ranges, most probably by active absorption. This process requires a constant expenditure of energy (for review see Wright 1991) which has to be met by the fish. In our experiments, an additional energy demand arose through direct consumption of glucose by trypanoplasms, which utilised significant proportions of the plasma glucose reserves.

In conclusion, carp with Trypanoplasma borreliassociated nephritis displayed increased electrolyte losses, probably because of disturbed re-absorption of ions in their distal renal tubule. The secretory and absorption processes of the proximal tubule appeared to be less affected during infection. Significant plasma hydration, as indicated by lowered plasma protein concentration, occurred only on Day 21 p.i. Infected carp were able to compensate their increased loss of ions and to maintain a normal electrolyte balance, most probably through (energy-consuming) active absorption processes. Carp infected by $T$. borreli appear to experience a serious drain on their energy budget, mainly due to direct consumption of plasma glucose by the parasites and increased expenditure for osmoregulation. In addition, $T$. borreli-infected carp experience an anaemia, which results in a serious shortage of oxygen required for metabolic processes.

Acknowledgements. Mr. S. H. Leenstra and Dr. G. Wiegertjes, Wageningen Agricultural University, The Netherlands, kindly provided fertilized carp eggs. We are grateful to Mrs. B. Schwerdt for chemical analysis of plasma and urine samples. This study was financially supported, in part, by a DFG grant to D.S.

\section{LITERATURE CITED}

Beyenbach KW (1995) Secretory electrolyte transport in renal proximal tubules of fish. In: Wood CM, Shuttleworth TJ (eds) Cellular and molecular approaches to fish ionic regulation. Academic Press, San Diego, p 85-105

Bunnajirakul S, Steinhagen D, Hetzel U, Körting W, Drommer W (2000) A study of sequential histopathology of Trypanoplasma borreli (Protozoa: Kinetoplastida) in susceptible common carp Cyprinus carpio. Dis Aquat Org 39: 221-229

Clifton-Hadley RS, Bucke D, Richards RH (1987) A study of the sequential clinical and pathological changes during proliferative kidney disease in rainbow trout, Salmo gairdneri Richardson. J Fish Dis 10:335-352 
Cowgill LD, Elliott DA (2000) Acute renal failure. In: Ettlinger SJ, Feldman EC (eds) Texbook of veterinary internal medicine, 5th edn. Saunders, Philadelphia, p 1615-1633

David JP, Osborne CA, Bartges JW, James KM, Churchill JA (1995) Chronic renal failure. In: Ettlinger SJ, Feldman EC (eds) Textbook of veterinary internal medicine, 4th edn. Saunders, Philadelphia, p 1734-1759

Elger B, Neukirch M, Hentschel H (1986) The kidney of rainbow trout, Salmo gaidneri Richardson, in the acute phase of viral haemorrhagic septicaemia: in vivo experiments on the renal excretion of fluid, electrolytes and protein. J Fish Dis 9:381-392

Elger M, Hentschel H, Dawson M, Renfro JL (2000) Urinary tract. In: Ostrander GK (ed) The laboratory fish. Academic Press, San Diego, p 385-413

Evans DH (1993) Osmotic and ionic regulations. In: Evans DH (ed) The physiology of fishes. CRC Press, Boca Raton, FL, p 315-341

Ferguson HW (1989) Systemic pathology of fish. Iowa State University Press, Ames

Hentschel H, Elger M (1987) The distal nephron in the kidney of fishes. Adv Anat Embryol Cell Biol 108:1-151

Houston AH (1990) Blood and circulation. In: Schreck CB, Moyle PB (eds) Methods for fish biology. American Fisheries Society, Bethesda, MD, p 273-334

Kakuta I, Namba K, Uematsu K, Murachi S (1986) Diurnal variation of urine properties of carp Cyprinus carpio. Bull Jpn Soc Sci Fish 53:2079-2089

Kakuta I, Namba K, Uematsu K, Murachi S (1992) Effects of hypoxia on renal function in carp, Cyprinus carpio. Comp Biochem Physiol A 101:769-774

Klontz GW, Smith LS (1968) Methods of using fish as biologi-

Editorial responsibility: Otto Kinne (Managing Editor),

Oldendorf/Luhe, Germany cal research subjects. In: Gay WI (ed) Methods of animal experimentation, Vol 3. Academic Press, New York

Lom J, Dyková I (1992) Protozoan parasites of fishes. Devel Aquac Fish Sci 26:1-315

Romeis B (1989) Mikroskopische Technik, 17th edn. Urban \& Schwarzenberg, München

Rudat S, Steinhagen D, Hetzel U, Drommer W, Körting W (2000) Cytopathological observations on renal tubule epithelium in common carp Cyprinus carpio under Trypanoplasma borreli (Protozoa: Kinetoplastida) infection. Dis Aquat Org 40:203-209

Scheinert P, Hoffmann R (1987) Qualitative und quantitative Verteilung von sieben Enzymen in Organen der Regenbogenforelle (Salmo gaidneri R.) und des Karpfens (Cyprinus carpio). J Vet Med Ser A 34:339-343

Steinhagen D, Kruse P, Körting W (1989) The parasitemia of cloned Trypanoplasma borreli Laveran \& Mesnil, 1901 in laboratory infected carp (Cyprinus carpio). J Parasitol 75: 685-689

Wolke RE (1992) Piscine macrophage aggregates: a review. Annu Rev Fish Dis 2:91-108

Wood CW, Patrick ML (1994) Methods for assessing kidney and urinary bladder function in fish. In: Hochachka PW, Mommsen TP (eds) Analytical techniques. Biochemistry and molecular biology of fishes, Vol 3. Elsevier, Amsterdam, p 127-143

Wright SH (1991) The interface of animal and aqueous environment: strategies and constraints on the maintenance of solute balance. In: Hochachka PW, Mommsen TP (eds) Phylogenetic and biochemical perspectives. Biochemistry and molecular biology of fishes, Vol 1. Elsevier, Amsterdam, p 165-180

Submitted: December 14, 2001; Accepted: April 2, 2002

Proofs received from author(s): June 14, 2002 